\title{
Reduction of population numbers of Melolontha spp. adults - a review of methods
}

\author{
Danuta Woreta
}

Forest Research Institute, Department of Forest Protection, Sękocin Stary, Braci Leśnej 3, 05-090 Raszyn, Poland, phone: 4822 7150551, fax: 22 7150557, e-mail: D.Woreta@ibles.waw.pl

\begin{abstract}
The article provides information about control of Melolontha spp. adults, the methods used in the past, chemical pest control as well as treatments applied today. In old times, cockchafer populations were reduced mechanically, by manual collection during the swarming period or by covering soil surfaces to prevent egg lying by females. Chemical pest control methods were introduced in the fifties of the $1900 \mathrm{~s}$, and in subsequent 50 years, they were improved to be less and less environmentally threatening. In many countries, including Poland, there have recently been introduced progressive restrictions on the use of insecticides in forestry. Banning chemical treatments against cockchafers resulted in going back to traditional methods and seeking alternate solutions, e.g. biological control agents. In the 1990 s, polyethylene nets were used to prevent egg laying in the soil by cockchafer females. At the same time, there was tested possible usefulness of a botanical insecticide derived from neem (Azadirachta indica) to combat cockchafer adults. The net, which needs to be spread flat on the ground, can be effective in orchards, however, in forested areas, the success of this method was limited due to the specific structure of forest land. In general, both methods stimulated no interest on the part of forestry on account of technical obstacles and too high cost of the botanical insecticide. Neglecting treatments toward reduction of cockchafer excessive numbers during their ongoing outbreak can bring about adverse changes in the forest structure.
\end{abstract}

\section{KeY WORDS}

Melolontha spp., chemical control, mechanical control, biological control

\section{INTRODUCTION}

The common cockchafer Melolontha melolontha L. and the forest cockchafer M. hippocastani Fabr. are important pests of forest nurseries and young plantations. At outbreak numbers, cockchafer larvae (white grubs) cause serious damage to seedlings and young trees, whereas adult beetles affect the condition of older trees through injuring the assimilation apparatus. Under Poland's climatic conditions, cockchafer development (from egg to beetle) usually lasts 4 years. Egg and larval stages go on hidden in the earth for more than $95 \%$ of cockchafer life time. Adult cockchafer beetles emerge in May, and for the next two months, they are seen in the canopy, feeding mainly on foliage of deciduous trees, and also - larch needles. After mating, females burry themselves in the earth (approx. $20 \mathrm{~cm}$ deep) and lay eggs. Egg laying is repeated several times, and in the meantime females fly back to 
the canopy and continue feeding on the leaves. Cockchafer swarming is the best time for pest control with the use of ground techniques or aerial treatments. Although white grubs feed out of sight on tree roots in the soil, at first, different cockchafer larval stages were combated with the use of particular methods. Currently, effective control of pest larval stages is unattainable, as no insecticide can be applied against white grubs due to the restrictive requirements of the Forest Stewardship Council (FSC), in addition to tightening legislation on the use of plant protection products in the EU's member states. As a consequence, control of cockchafer beetles has become the only way to reduce excessive pest population numbers. The process of combating cockchafers, and other insect pests likewise, has undergone several stages of human awareness and competence. Initially, mechanical methods were used, next destructive chemical treatments were applied, followed by selective chemical methods, and now - mechanical methods have returned or biological control agents are used.

\section{Mechanical and biological measures}

\section{Methods used in the past}

Mechanical destruction of cockchafers is the oldest method used for reducing excessive numbers of these pests. In Poland of the 1930s, shaking adult cockchafers from trees, next collecting and destroying were commonly used methods (Maciejowski 1936; Petrykowski 1937). Earlier, all-inclusive action plans were elaborated before cockchafer swarming flights, with detailed maps of threatened areas in individual forest districts. A necessary equipment was prepared and staff was trained (Remiszewski 1899).

In forest nurseries, there were recommended installations of net covers above seedlings or - dense metal grids, safeguarding trees from the top and all sides (Badeni 1894). It was believed that different kinds of lattice would also protect young trees against birds (Janeczko 1906). Besides, young trees were also covered with cut down tree branches, dry leaves or litter. Furthermore, efforts were undertaken to deter cockchafer females and discourage them from egg laying with pungent smell of walnut leaves (Janeczko 1906). The leaves were buried in the soil or water leaf extract was poured on the ground around trees. Also, wooden boxes filled with loosened soil were displayed so as to attract cockchafer females to lay eggs. These were inspected after white grubs hatched and found specimens were destroyed (Remiszewski 1899).

\section{Methods used nowadays}

Now, polyethylene fine mesh covers are used to protect the soil against cockchafer egg laying. These are specially produced to be spread out on the soil in the areas with flying females, who are not able to get through mesh to burry eggs in the soil. Adult cockchafers emerging from the soil under the mesh cannot fly out and take part in mating or to complete secondary feeding in the canopy. Net usefulness has been tested, among others, in Italy and Switzerland. In Terentino (Italy), before cockchafer swarming flights, 150 ha of orchards and vineyards were covered with nets in the year 1991, and in 1995 - 250 ha (Varner and Mattedi 1996). The obtained results showed that in covered soils, there occurred on average 3 white grubs $/ \mathrm{m}^{2}$, and in the control areas (uncovered) -29 white grubs $/ \mathrm{m}^{2}$. At the same time, the minimum grub numbers in covered and control areas were $\mathrm{O}$ and 5 white grubs $/ \mathrm{m}^{2}$, respectively and the maximum -8 and 99 white grubs $/ \mathrm{m}^{2}$, respectively. W 1995, at lower pest densities, on average 0.4 white grubs $/ \mathrm{m}^{2}$ were observed in the covered areas, and -7.5 white grubs $/ \mathrm{m}^{2}$ in the control. In orchards, better results were obtained in the soil between tree rows when compared to the soil under tree rows (at fastening of net edges). Under laboratory conditions, cockchafer females collected underneath nets were fed for subsequent 10 days on the leaves of herbaceous plants. The eggs of these females showed considerably delayed development, when compared to the eggs of females collected from the canopy and fed on the leaves of oak and birch. Within 10-day-period, $90 \%$ of females feeding on tree leaves had fully developed eggs, and there was observed the beginning of egg development in $7 \%$ of females from this group. In the group of females fed on herbaceous plants, $50 \%$ developed no eggs and in 50\% - eggs indicated the beginning of development (Varner and Mattedi 1996).

In 1992, in the Unterland region (Italy), $65 \%$ of the soil in the area with recorded swarming cockchafers was covered with nets (Zelger 1996). In 1995, previous to less intensive cockchafer swarming flights, the areas were covered again. In subsequent years, no tree damage was observed as well as considerable reduction of white 
grub numbers was noted in the whole area covered with nets. In the spring 1994, in Switzerland (Brenneri and Keller 1996), 150 ha of orchards were covered with nets in the period of cockchafer swarming. In the covered areas, there were observed reduced populations of white grubs. Within the areas protected, grub numbers were below the critical threshold values. Cockchafer females found underneath the nets were able to lay a small number of fertilized eggs, although they did not take part in the swarming flight and did not feed in the canopy. Application of nets in forestry would be an expensive undertaking as well as labor consuming - especially in newly reforested areas. Up to date, the effectiveness of this method has not been tested in Poland.

At some stage in the ongoing cockchafer outbreak, there was examined a possibility to combat adult beetles with a botanical insecticide, with the active ingredient derived from neem (Azadirachta indica A. Juss., Meliacea). Along with lesser biologically active substances, neem seed extract contains azadirachtin (AZT), which strongly affect insects from a range of systematic groups (Schmutterer 1985, 1995). In the 1990's, Kaethner (1991) and Schmutterer (1995) investigated the effects of these compounds on cockchafers, using water emulsion of neem seed oil at the concentration $500 \mathrm{ppm}$, AZT extracts (500 ppm and $1000 \mathrm{ppm}$ ) as well 3\% seed oil. Preliminary results obtained in the tests on the forest cockchafer treated with water emulsion of seed oil at the concentration $500 \mathrm{ppm}$ showed antifeeant activity of the formulation, cockchafer mobility reduction and longevity decrease in the insects treated when compared to the control. The evaluation of the effects of AZT-extracts (500 ppm and $1000 \mathrm{ppm}$ ) when compared to those of $3 \%$ oil on common and forest cockchafers, confirmed the results obtained earlier, and also showed sterilization effects of the bioinsectide formulations tested on both cockchafer species observed (Kaethner 1991). The reduction of the numbers of eggs laid was observed under laboratory conditions as well as in field tests. Only small numbers of treated females were able to reproduce, and egg masses laid by capable females were half as big when compared with the control population.

In 1995, there was carried out a trial in Germany, on common cockchafer control with the use of preparation based on neem seeds - Neem Azal- T/S (1\% concentration) (Schnetter et al. 1996). The results obtained confirmed preparation efficacy as feeding inhibitor as well as hormonal control agent holding back development of eggs and oviposition. Under favorable conditions, Neem Azal T//S can almost fully prevent egg laying by cockchafer females. Treated females laid 3\% of the number of eggs laid by control females. According to Rhode (1996) under field conditions, Neem Azal T/S showed no striking effects on forest cockchafer adults, however, it changed their behavior. A few (2-3) days after bioinsecticide treatments, cockchafer beetles stopped feeding, swarming activity decreased and the numbers of eggs laid by females were considerably reduced.

\section{In search for new methods}

More and more restraining approach to the application of chemical insecticides in the protection of forest instigated the interest in alternate means to control cockchafer population numbers.

Before the era of chemical insecticides, cockchafer harmfulness was to be decreased by planting certain tree species (e.g. around a forest nursery), recognized as not attractive to cockchafers (Różyński 1926). The study with the aim to determine the effect of different diets on maturity and longevity of cockchafer adults was carried out in the Forest Research Institute, Poland by Woreta and Sukovata (2010) and Woreta et al. (2016). In 2010, under laboratory conditions, there were investigated the effects of the leaves of pedunculate oak Quercus robur L. and common hornbeam Carpinus betulus L., silver birch Betula pendula Roth. and black alder Alnus glutinosa L. on maturity of forest cockchafer beetles. The results showed that life span of specimens that fed on the leaves of pedunculate oak was on average 23.57 days, silver birch -20 days, common hornbeam - 19.3 days, and black alder -11.1 days. Except for forest cockchafer males feeding on oak leaves, the average length of life in males was lesser when compared to females. The survival rate in both forest cockchafer females and males was the highest when fed on pedunculate oak leaves. On black alder, $100 \%$ mortality of males and females was observed after 10 and 15 days of feeding, respectively. The majority $(90 \%)$ of females feeding on oak leaves laid eggs (from 15 to 68, on average 37.4/ female), whereas only $1 \%$ of females feeding on hornbeam leaves laid eggs. Those feeding on silver birch and black alder laid no eggs (Woreta and Sukovata 2010).

In the study carried out in the years 2011-2013 (Woreta et al. 2016), common cockchafer and for- 
est cockchafer adults were fed on pedunculate oak (Q. robur) leaves, as well as those of sessile oak Q. petraea (Matt.) Liebl., common beech Fagus sylvatica L., silver birch, black alder, European larch Larix decidua Mill., common hornbeam, false acacia Robinia pseudoacacia L., black cherry Prunus serotina (Ehr.) Borkh., rowan Sorbus aucuparia L. em. Hedl. and black elder Sambucus nigra L. The leaves of the two oak species constituted the most beneficial diet for adults of both cockchafer species in terms of their survival, body weight gain and fecundity. Common hornbeam leaves and European larch needles represented better diet for the common cockchafer when compared to the forest cockchafer. Common beech and rowan leaves were better diet for the forest cockchafer. Silver birch leaves moderately supported forest cockchafer maturity and had adverse effect on the common cockchafer. False acacia and black cherry leaves constituted poor diets for females of both cockchafer species. Cockchafer females feeding on the leaves of black alder and black elder laid no eggs.

In the framework of the project realized by the Forest Research Institute, there was also conducted a study with the aim to evaluate prospects of botanical insecticides as control agents against adult cockchafers (Skrzecz et al. 2014). Antifeedant activity of flavonoids (rutin and quercetin) derived from buckwheat Fagopyrum esculentum Moench as well as black alder extracts were tested in the trials on the common cockchafer. The insects fed on pedunculate oak leaves sprayed with the substances evaluated. Common cockchafer adults feeding on the leaves treated with rutin showed greater mortality, decreased feeding intensity as well as reduced fecundity. At the same time, no effects of quercetine and black alder extract treatments were found. The results of the choice tests carried out under semi-field conditions, showed that adults avoided feeding on the leaves sprayed with rutin suspension (Skrzecz et al. 2014).

\section{Chemical methods}

\section{DDT and HCH treatments}

New perspectives in control of harmful insects, including important forest pests, such as cockchafers, were brought about in the late 1940s (after the 2-nd World
War) by the progress made in development of chemical methods. Initial trials to combat adult cockchafers with the use of contact insecticides from the group of chlorinated hydrocarbons, were performed in Germany and Switzerland, in 1948 and 1949. There were applied liquid insecticide formulations with lindane (gammahexachlorocyclohexane) as the active ingredient (Gemperli 1950; Gersdorf 1950; Müller 1950). The treatment was carried out with the ground spray equipment - a wheeled vehicle with fixed 10001 container with an attached spraying apparatus. The insecticide was sprayed onto the edges of forest stands situated along roads. The equipment used allowed for sprays onto 30-50 m distant stand edges. In Switzerland, insecticide liquid preparation (based on hexane) was applied in 1948, along $5.3 \mathrm{~km}$-long forest edge, and in 1949 - about $100 \mathrm{~km}$-long (Gemperli 1950). The treatments performed considerably reduced white grub population numbers in the region. In the area of the former Soviet Union, first trials on control of cockchafer white grubs with DDT and HCH were conducted in 1948 (Lebiediewa 1950). Next, in 1951, there were carried out aerial sprays of 473 ha of deciduous forests infested by adult cockchafers (Lebiediewa 1952). The trials involved powder insecticide formulations at the rates: $\mathrm{HCH}-30 \mathrm{~kg} / \mathrm{ha}$ and $15 \mathrm{~kg} / \mathrm{ha}$ and DDT $-15 \mathrm{~kg} / \mathrm{ha}$. It was observed that higher $\mathrm{HCH}$ and DDT rates caused just about instantaneous drop of cockchafers down to the ground. Based on the results obtained, there was decided that the treatments with the preparations tested would be successful in combating cockchafers at the rates: $15 \mathrm{~kg} / \mathrm{ha}$ of $10 \%$ DDT and $20 \mathrm{~kg} / \mathrm{ha}$ of $12 \% \mathrm{HCH}$.

At that time, in Poland it was believed that soil applications of insecticides should be used against white grubs, due to better selectivity when compared to the treatment of open areas (Schnaider and Karlikowski 1954). Adult cockchafers were treated with powder and liquid preparations at first, and later aerosols were used (Sierpiński 1975).

In Poland, first treatments against adult cockchafers were applied in the western regions of the country in 1968, on the area of approximately 100 ha (Pawłowicz 1969). The treatment was applied against forest cockchafer adults in pine stands with birch and European larch admixture, oak stands and Scots pine stands with oak undergrowth, using manual and engine knapsack spray equipment. The preparation used was a product 
Mgławik, which indicated high efficacy at a rate $81 /$ ha (Sierpiński 1975). Mgławik formulation was commonly used in the 1960 s and recommended as a universal control agent of leaf eating insects. At first, it contained $10 \%$ DDT and about 5\% lindane, and later - 8\% DDT and 2\% lindane (Malinowski 1997). In the 1970s, DDT was banned in Poland (likewise in other countries) due to revealed wide spectrum of its activity against living organisms, including natural enemies of harmful insects and the fact that chemicals of this kind cumulated in the soils, waters as well as animal and human bodies (Malinowski 2003). Insecticides with lindane - widely used in forestry, agriculture and horticulture (including orchards) in the 1960s-1970s - considerably reduced cockchafer population numbers. In 1980-1993, damages due to white grubs in forests were observed only in nurseries and on small areas of young plantations (Woreta 1994).

\section{Application of pyrethroids}

Around 1980, novel pesticide formulations containing pyrethroids were introduced as plant protection products - moderately toxic to warm-blooded organisms, including humans, and highly effective against insects when applied at low rates (Malinowski 1982; Malinowski and Korczyński 1980). Pyrethroids are highly effective insecticides with contact and gut activity. They do not penetrate plant tissues and are most effective at temperatures below $20^{\circ} \mathrm{C}$ (Głowacka and Olczyk 2009).

For the last 20 years, in Poland there has been observed the ongoing cockchafer outbreak (Woreta 1995, 2013), likewise in other European countries (Zelger 1996; Brenner and Keller 1996; Strasser and Schinner 1996; Kronauer 2010; Švestka 2010). In the first years of the outbreak in Poland, against adult cockchafers, there were used, among others, the following plant protection products with pyrethroids as the active ingredients: Decis 2.5 EC - deltamethrin, Fastac 10 EC -alphamethrin, Alfazot $05 \mathrm{EC}$ - alphamethrin, Sumi alpha 0,25 EC - esfenvalerate, Karate 10 EC - lambdacyhalothrin and Zorro 100 EC- zeta cypermethrin (Głowacka 1997). In 1996, control treatments against common cockchafer adults were conducted in the Nidzicka Forest (Adomas 1998). A plant protection product Fastac 10 EC

was applied on the area of 377 ha with the use of Mi-2 helicopter. The treatment comprised the areas with white grub damage observed in the previous year and was assessed as effective. In the trials carried out in other countries, there was also observed high efficacy of Decis 2.5 EC (Rhode 1996) and Karate 5 EC (Benker i Leuprecht 2007). Similar high mortality of cockchafers was observed after treatments with Rubitox with the active ingredient phosalone (Rhode 1996). Woreta (1999) tested sensitivity of cockchafer adults to pyrethroids under laboratory conditions and showed that alphamethrin, deltamethrin, lambdacyhalothrin and zeta cypermethrin applied at low rates cause high insect mortality. In 2003, in the Czech Republic (southern Moravia), there was used Decis EW 50 against forest cockchafer adults (Švestka 2010). The aerial treatment was aerially applied on 508 ha with the use of the helicopter. As the result, dying adult specimens were observed even 3 days after application of insecticide. In Poland, especially large areas were treated chemically during the swarming fly of cockchafer adult generation emerging every 4 years in our country since 1995 (1999, 2003, 2007, 2011) (Woreta 2013). During the swarming period in 1995, cockchafers were recorded on 15 thousand ha, and in 1999, 2003, 2007, 2011 - on 26 thousand ha, 46 thousand ha, 99 thousand ha and 121 thousand ha, respectively. In 1995, pyrethroids and Trebon 10 SC (aryl-propyl ether) were used in the treatments on approximately 7 thousand ha. High efficacy of the treatment was observed (Woreta 1996). In 2003, pyrethroids were applied against cockchafers on 17.9 thousand ha, of which -13.8 thousand ha were carried out within the area administered by the Regional Directorate of State Forests Łódź (Woreta 2004). Within the latter area, aerial treatments were carried out against swarming cockchafers with the use of Fastac 10 EC. The treatment comprised the areas with white grub damage observed for years. The results of field examinations showed that high mortality was observed right after the treatment, however the activity of the product used did not last long enough. A week after the treatment, it was observed that cockchafer adult flied onto sprayed trees and started feeding. Under good weather conditions, cockchafers swarm for a period longer than one month, therefore pyrethroid treatments should be repeated (Głowacka and Olczyk 2009). There should be taken into account, that when common and forest cockchafer occur within one area, adult cockchafer activity can be observed during the period that can last even 2 months (Olczyk 2011). 


\section{Possible means of control of cockchafer adults in forests at the present time}

During cockchafer swarming in 2007 and 2011, 100 -year-old control method was used, i.e. manual collections of adult specimens. In 2007, the area of 20.6 thousand ha was subject to treatments against cockchafers; 13.6 thousand ha was sprayed with insecticides, and manual collection of cockchafer beetles was performed on the area of 13.2 thousand ha. On some parts of the total area treated, there were applied both control means (chemical as well as mechanical methods). Insecticide treatments were performed with the use of a mixture of Decis 2.5 EC (pyrethroid) and Mospilan 20 SP (neonicotynoid) (Woreta 2008; Głowacka and Olczyk 2009). There was obtained high efficacy of the treatment. In 2008, all the pyrethroids were included in FSC "highly hazardous list" of chemical pesticides (Głowacka 2008).

In Germany, soil application of insecticides against white grubs was banned at the beginning of the 1980s, and since 2000, there has been banned a plant protection product Rubitox (pyrethroid) - earlier used against adult cockchafers (Schröter 2000; Rohde and Gossenauer-Marohn 2000).

In 2011, Poland's Ministry of Agriculture and Rural Development granted a permission to use a plant protection product Mospilan 20 SP against then swarming adult cockchafers (prolific generation that emerges every 4 years in Poland). The treatments with Mospilan $20 \mathrm{SP}$ were conducted on forested area of 44.9 thousand ha. At the same time, cockchafer adults were manually collected within an area of 1708 ha (Woreta 2012). Cockchafer chemical control was applied in threatened forests managed by the Regional Directorate of State Forests Łódź, on an area of 10 thousand hectares. Mospilan $20 \mathrm{SP}$ is an insecticide from the class of neonicotinoids, and its active ingredient is acetamiprid. Neonikotinoids are insecticides with contact-gut activity against insects. These are systemic chemical substances, transported within tissues of plant organs, including the leaves. In comparison to pyrethroids, neonicotinoids are less sensitive to temperatures (Głowacka and Olczyk 2009). The results of evaluation of treatment efficacy carried out right after spraying, showed that both Mospilan 20 SP mixed with Decis 2.5 EC (applied in 2007), as well as Mospilan 20 SP alone caused high mortality of cockchafer adults and protected tree leaves against damage (Głowacka and Olczyk 2009). Evalua- tions carried out later indicated considerable reduction of white grub population numbers in the sprayed areas, when compared to those untreated. The assessments also included leaf biomass loss due to cockchafer feeding Mospilan 20 SP treated and control plots (Głowacka 2012). Three weeks after the treatment, 144 Q. robur leaves were collected from the experimental and control plots for further analyses under laboratory conditions. The assessment of leaf damage was performed with the use of the computer program LIŚĆ. The results showed that Mospilan 20 SP treatments protected $90 \%$ of oak leaves against adult cockchafer feeding.

West of Poland, in Germany, there has been lately detected the risk of mass cockchafer occurrence, especially in the southern parts of the country (Baden - Württernberg, southern Hessia) (Zimmermann 2004). In the years 2006 and 2010, there were recorded swarming flights of the forest cockchafer emerging in southern regions every 4 years (Bressem and Kolb 2006; Kronauer 2010). In 2010, the results of the assessments of white grub population in the areas situated in between Gross - Gerau, Darmstad and Lampertheim showed, that there should be performed control treatments against the forest cockchafer. On average, 9 white grubs $/ 1 \mathrm{~m}^{2}$ were found in the soil, and the highest number observed was 100 specimens/sample, therefore an urgent necessity for pest control was stressed, in view of the threshold level: 3 L3 white grubs $/ 1 \mathrm{~m}^{2}$ (Kronauer 2010). According to the author of the paper cited, cockchafers seem to be especially protected. Otherwise, it is impossible to understand lack of reasoned control of this pest. On the one hand, forests are safeguarded against application of toxins as valuable habitat of living organisms, and on the other - the restrictions concerning pest control in fact protect cockchafers and enhance their population numbers. As a consequence, future generations of voracious white grubs feeding on tree roots, pose a threat to sustainability of forests protected against toxins. In 2007, in the region of Freiburg (Kronauer 2007), control of excessive numbers of adult cockchafer populations was impossible due to the fact that the majority of the area threatened by swarming pests was under some kind of protection (e.g. water retention forest, Natura 2000 site). Reasonable arguments concerning the consequences of pest activity and economic losses (e.g. additional costs of establishment of new plantations) were of no use (Kronauer 2007). In Baden - Württernberg (Ott et al. 2006), the observed 
cockchafer population density exceeded the threshold value. Under such circumstances, the lack of effective control measures will lead to greater and greater damage due to white grubs in young plantations and older stands. If the approach to the protection of forests against cockchafers does not change, maintenance of the current forest structure will be hard to accomplish. As a result - in place of forests, there will grow lawns and black cherry bush (Ott et al. 2006).

\section{Conclusion}

Decisions on the protection of forests should be made by foresters who have knowledge on functioning of forest communities and eliminating of threats. Things are not going well, if the decisions on forest protection are not taken by practitioners but management theoreticians, who often have nothing to do with realistic assessments of pest risk in forests. Cockchafer threat is evaluated based on the number of white grubs found in the soil. In Poland, in the document: Guidelines on the Protection of Forest, there are provided threshold values with reference to cockchafer population numbers acceptable in view of maintaining forest sustainability. White grub population numbers higher than the threshold level cause irreversible damage to tree and shrub roots. Therefore, sustainability of all forests, and especially young is seriously threatened, both those managed and under different kinds of protection.

\section{References}

Adomas J. 1998. Controlling may beetle (Melolontha melolontha L.) in the Puszcza Nidzicka (RDSF Olsztyn) in 1996 (in Polish with English summary). Sylwan, 142 (11), 95-100.

Badeni A. 1894. The main swarming of common cockchafer in 1894 (in Polish). Sylwan, 132-134.

Benker U., Leuprecht B. 2007. The swarming flight of common cockchafer Melolontha melolontha L. (Coleoptera, Scarabaeidae) in two different areas and an approach to control the egg deposition. $I O B C /$ WPRS Bulletin, 30 (7), 91-94.

Brenner H., Keller S. 1996. Protection of orchards from white grubs (Melolontha melolontha L.) by placements of nets. Integrated control of soil pests. IOBC/WPRS Bulletin, 19 (2), 79-82.

Bressem U., Kolb M. 2006. Waldschutzsituation 2005/2006 in Hessen. AFZ der Wald, 61, 7, 348-350.

Gemperli L. 1950. Neuer Verfahren im Kampf gegen den Mäikäfer. Schweizerische Zeitschrift für Forstwesen, 4, 166-167.

Gersdorf E. 1950. Über die Verwendbarkeit neuartiger Insekticide zur Maikäferbekämpfung. Anzeiger für schädlingskunde, 4, 53-55.

Głowacka B. 1997. Insecticides recommended in forest protection in 1997 (in Polish). IBL, Warszawa.

Głowacka B., Olczyk M. 2009. The effectiveness of treatments to combat agricultural aviation imagines cockchafer Melolontha sp. (in Polish). Notatnik Naukowy IBL, 6 (86).

Głowacka B. 2007. Plant protection products recommended for use in forestry in 2008 (in Polish). Analizy i Raporty, 9, 3-60.

Głowacka B. 2012. Plant protection products and products for the distribution of forest tree trunks recommended for use in forestry in 2013 (in Polish). IBL, Sękocin Stary.

Janeczko M. 1906. The extermination of insect pests at nurseries (in Polish). Sylwan, 41-49.

Kaethner M. 1991. Untersuchungen über die Eingnung von Nemsamenprodukten zur Bekämpfung des Waldmaikäfers Melolontha hippocastani F. des Feldmaikäfers $M$, melolontha L. (Col. Scarabaeidae). Journal of Applied Entomology, 112, 345-352.

Kronauer H. 2007. Zu viele Waldmaikäfer im Hardtwald bei Karlsruhe. AFZ der Wald, 62 (13), 692-694.

Kronauer H. 2010. Massenvermehrung im Hessischen Ried. Prozessschutz für Waldmaikäer in Hessen. AFZ der Wald, 65 (6), 36-37.

Lebiediewa L. 1950. Opyt primienienja dustow DDT i HCH protiw liczinok majskowo chruszcza. Lesnoje Chozjajstwo, 5, 65-68.

Lebiediewa L. 1952. Chimiczeskaja borba s żukami majskowo chruszcza. Lesnoje Chozjajstwo, 5, 79-81.

Maciejowski K. 1936. Fighting cockchafer in state forests (in Polish). Las Polski, 12, 33-40.

Malinowski H. 1982. The effect of temperature on the insecticidal activity of photostable pyrethroids (in Polish). Roczniki Nauk Rolniczych, Seria E, 12 (1/2), 245-255. 
Malinowski H. 1997. Basics protect nurseries and forest plantations and agricultural against pest roots (in Polish). Oficyna Wydawnicza OIKOS, Warszawa.

Malinowski H. 2003. Insect resistance to insecticides (in Polish). Wieś Jutra, Warszawa.

Malinowski H., Korczyński J. 1980. Toxicity photostable pyrethroids for some arthropods compared with other insecticides (in Polish). Roczniki Nauk Rolniczych, Seria E, 10 (12), 175-185.

Müller F. 1950. Maikäferbekämpfung. Anzeiger für Schädlingskunde, 9, 131-132.

Olczyk M. 2011. Limiting the population of beetles Melolontha spp. on RDSF Łódź. History, present and thoughts for the future (in Polish). Postępy Techniki w Leśnictwie, 116, 14-23.

Ott A., Delb H., Mattes J., Schröter H. 2006. Erfolgreiche Regulierung eines Nebenflugstammes des Waldmaikäfers. AFZ der Wald, 61 (6), 312-315.

Pawłowicz J. 1969. How to combat the beetle at Forest District Rzepin (in Polish). Las Polski, 24, 15.

Petrykowski A. 1937. Gathering beetle (in Polish). Niwa Leśna, 4.

Remiszewski K. 1899. Quo usque tandem Melolontha? (in Polish). Sylwan, 136-141.

Rohde M. 1996. Experiments to reduce Melolontha hippocastani F. damages in the Hessian Rhein-MainPlain. IOBC/WPRS Bulletin, 19 (2), 89-94.

Rohde M., Gossenauer-Marohn H. 2000. Stand der Waldmaikäfer - Gradation in der hessischen Rheinebene. AFZ der Wald, 55 (7), 372-374.

Różyński F. 1926. Fighting against a common cockchafer (in Polish). Przeglad Leśniczy, 1, 32-38.

Schmutterer H. 1985. Which insects can be controlled by application of neem seed kernel extracts under field conditions. Zeitschrift für Angewandte Entomologie. 100, 468-475.

Schmutterer H. 1995. The neem tree. VCH Verlagsgesellschaft mbH, D-69451 Weinheim Bundesrepublik Deutschland ss. 696.

Schnaider Z., Karlikowski T. 1954. Some investigations upon combating of cockchafer larvae by chemical means (in Polish). Prace IBL, 109, 89-107.

Schnetter W., Mittermiiller R., Fröschle M. 1996: Control of the cockchafer Melolontha melolontha in the Kreichgau with Neem Azal - T/S. IOBC/WPRS Bulletin, 19 (2), 95-99.
Schröter H. 2000. Neue Erkenntnisse zur Bekämpfung des Waldmaikäfers (Melolontha hippocastani F.). Nachrichten Blatt des Deutschen Pflanzenschutzdienstes, 52 (6), 139-144.

Sierpiński Z. 1975. Important insects - pests roots of forest trees and shrubs (in Polish). Państwowe Wydawnictwo Rolnicze i Leśne, Warszawa.

Skrzecz I., Sowińska A., Janiszewski W. 2014. Impact of botanical antifeedants on the development of Melolontha melolontha L. (in Polish). Sylwan, 158 (10), 779-786.

Strasser H., Schinner F. 1996. Current status of Melolontha melolontha control by the fungus Beauveria brongniartii in Austria. IOBC/WPRS Bulletin, 19 (2), 69-73.

Švestka M. 2010. Changes in the abundance of Melolontha hippocastani Fabr. and Melolontha melolontha (L.) (Coleoptera: Scarabeidae) in the Czech Republic in the period 2003-2009. Journal of Forest Science, 56, 417-428.

Varner M., Mattedi L. 1996. Experiences about the control of the common cockchafer (Melolontha melolonntha L.) in Trentino by means of plastic nets. IOBC/WPRS Bulletin, 19 (2), 83-88.

Woreta D. 1994. Changes in the occurrence of pests of forest trees and bushes roots in 1961-1993 (in Polish). Sylwan, 5, 37-41.

Woreta D. 1995. The alarming increase in the importance cockchafer including amphimallon solstitiale (in Polish). Głos Lasu, 8, 13-15.

Woreta D. 1996. Melolontha. In: Assessment of the most important forest pests and infectious diseases in Poland in 1995 and the forecast of their occurrence in 1996 (in Polish). IBL, 85-86.

Woreta D. 1999. Biological activity of insecticides used to control Melolontha spp. adults (in Polish with English summary). Prace IBL, 869, 61-74.

Woreta D. 2004. Melolontha. In: The short-term forecast of occurrence of major pests and infectious diseases of forest trees in Poland in 2004 (in Polish). Analizy i Raporty, 1, 75-77.

Woreta D. 2008. Melolontha. In: The short-term forecast of occurrence of major pests and infectious diseases of forest trees in Poland in 2008 (in Polish). Analizy i Raporty, 10, 91-93.

Woreta D. 2012. Melolontha. In: The short-term forecast of occurrence of major pests and infectious 
diseases of forest trees in Poland in 2012 (in Polish). Analizy i Raporty, 18, 87-89.

Woreta D. 2013. Melolontha. In: The short-term forecast of occurrence of major pests and infectious diseases of forest trees in Poland in 2013 (in Polish). Analizy i Raporty, 20, 90-92.

Woreta D., Sukovata L. 2010. Effect of food on development of Melolontha hippocastani F. beetles ( $\mathrm{Co}-$ leoptera, Melolonthidae) (in Polish). Leśne Prace Badawcze, 71 (2), 195-199.

Woreta D., Lipiński S., Wolski R. 2016. Effects of food source quality on the adults of Melolontha melolon- tha and M. hippcastani (in Polish). Leśne Prace Badawcze, 77 (1) 14-23.

Zelger R. 1996. The population dynamics of the cockchafer in South Tyrol since 1980 and the measures applid for control. IOBC/WPRS Bulletin, 19 (2), 109-113.

Zimmermann G. 2004. Vorkommen und Bekämpfung der Maikäfer in Deutschland: Ein historischer Rückblick. Nachrichten Blatt des Deutschen Pflanzenschutzdienstes, 56 (5), 85-87. 